\title{
BESIBERRIS GLACIGENIC ROCK GLACIER (CENTRAL PYRENEES, SPAIN): MAPPING SURFACE HORIZONTAL AND VERTICAL MOVEMENT (1993-2003)
}

\author{
J. CHUECA CÍA ${ }^{(1) *}$ y A. JULIÁN ANDRÉS ${ }^{(2)}$ \\ ${ }^{1}$ Departamento de Geografía y Ordenación del Territorio; \\ Facultad de Ciencias Humanas y de la Educación; \\ Universidad de Zaragoza; 22002-Huesca \\ ${ }^{2}$ Departamento de Geografía y Ordenación del Territorio; \\ Escuela Politécnica Superior; \\ Universidad de Zaragoza; 22071-Huesca
}

\begin{abstract}
A ten-year (1993-2003) geodetic survey was conducted at the Besiberris rock glacier, a tongue-shaped, glacigenic rock glacier, located in the eastern-central Spanish Pyrenees (4235'48“N, 049'20"E). Displacement measurements were made on three traverse lines across the rock glacier and mapped by geostatistical kriging interpolation methods. Surface horizontal velocity increases from the head to the toe sectors (average values: traverse line A $=8.72 \mathrm{~cm} \mathrm{yr}^{-1}$; line $B=10.65 \mathrm{~cm} \mathrm{yr}^{-1}$; line $\left.C=13.35 \mathrm{~cm} \mathrm{yr}^{-1}\right)$. Velocities are greater at the axis of the rock glacier compared to its lateral margins. In terms of vertical movement, the rock glacier has shown clear thinning of an ice-core. In all three traverse lines, surface lowering has been detected (average values: line $A=5.00 \mathrm{~cm} \mathrm{yr}^{-1}$; line $B=7.10 \mathrm{~cm} \mathrm{yr}^{-1}$; line $\left.C=5.27 \mathrm{~cm} \mathrm{yr}^{-1}\right)$. This general lowering is interpreted as the adjustement of the rock glacier to the climatic amelioration (higher temperature, drier conditions and reduced snowfall) observed in the Pyrenean region since the end of the Little Ice Age and accentuated in the last few decades.
\end{abstract}

Key words: rock glacier, movement cartography, Pyrenees.

Enviado el 12 de noviembre de 2010 Aceptado el 20 de marzo de 2011

*Correspondencia: Departamento de Geografía y Ordenación del Territorio; Facultad de Ciencias Humanas y de la Educación; Universidad de Zaragoza; 22002-Huesca. E-mail: jchueca@unizar.es 


\section{Introduction}

Rock glaciers are significant mass wasting landforms in the Pyrenees, but they are mainly relict, showing in most cases no signs of present-day activity (Chueca, 1991, 1994). A first analysis of the spatial distribution of rock glaciers in the Central Pyrenees was made by Chueca (1992), who identified 170 rock glaciers in the Spanish (southern) Pyrenean area and determined that lithology and fracturing density were important distribution controls. Serrano et al. (1999) classified 13 active rock glaciers located both in the Spanish and French sides of the Pyrenees in morphogenetical terms, using two categories typically mentioned in the literature: talus rock glaciers (periglacial origin) and debris rock glaciers (glacigenic origin, linked to morainic deposits incorporated by glaciers) ( $c f$. Barsch, 1996; Clark et al. 1998). In this paper, we present a ten-year geodetic survey on Besiberris glacigenic rock glacier (one of the morphologies mentioned by Serrano et al., 1999) mapping by geostatistical kriging interpolation methods its surface horizontal and vertical movement and analyzing the observed differential spatial dynamics.

Velocity measurements by geodetic techniques have been carried out in a reasonable number of rock glaciers located around the world, mainly in alpine environments, but few observations cover long, decadal periods (Potter, 1972; Benedict et al., 1986; Francou and Reynaud, 1992; Gorbunov et al., 1992; Sollid and Sorbel, 1992; Whalley et al., 1995; Barsch, 1996; Potter at al., 1998; Sloan and Dyke, 1998; Koning and Smith, 1999). More recently, photogrammetry and digital photogrammetry have also been applied to determine surface displacements using multi-year aerial photographs (Kääb et al., 1997, 2002; Kaufmann, 1998; Kaufmann and Ladstädter, 2003; Kääb, 2006). In the Pyrenees, only the Argualas and Posets rock glaciers, of periglacial origin and placed in the Panticosa and Posets massifs (Serrano et al. 2006, 2010), and the Besiberris rock glacier, of glacigenic origin (Chueca and Julián, 2005), have been surveyed using geodetic techniques during a several-years period.

Besiberris rock glacier first descriptions were made by Serrano et al. (1991) and Chueca et al. (1992). The existence of activity in the rock glacier was inferred from several facts: (1) absence of vegetation and limited lichen growth; (2) marked unstability of the frontal talus, with evidences of rock slides and micro debris-flow processes; (3) presence of an apron of fresh coarse boulders at the foot of the frontolateral slopes. The geodetic measurements began in 1993. Movement data from several traverse sections allow a better evaluation and understanding of rock glacier velocity and dynamics than a single line or isolated points; therefore, three traverse lines that control the rock glacier dynamics in its proximal, central and distal sectors were established. In 2003 displacements were measured, obtaining data for the three transects. The aim of this work is twofold: (1) to present the results of surface velocities and vertical displacements from 1993-2003 and map them by using kriging geostatistical interpolation techniques; (2) to identify differential spatial dynamics of the rock glacier. 


\section{Study area}

Besiberris rock glacier is located in the eastern-central Spanish Pyrenees (Fig. 1). The Besiberris mountains are composed of weathering-resistant and highly fractured granites and granodiorites. They are mainly aligned in a N-S trend, acting as a drainage divide between Noguera Ribagorzana and Noguera de Tor river valleys (Besiberri N, 3014 m; Besiberri del Mig, 3002 m; Besiberri S, 3030 m). Minor, relatively low ridges stretch east-west from this principal ridge (Tuc Comtessa, 2760; Tossal de Mola Gran, 2885; Pic d'Avellaners, 2965; Pic de la Torreta, 2951; Pic d'Escobedieso, 2800). The

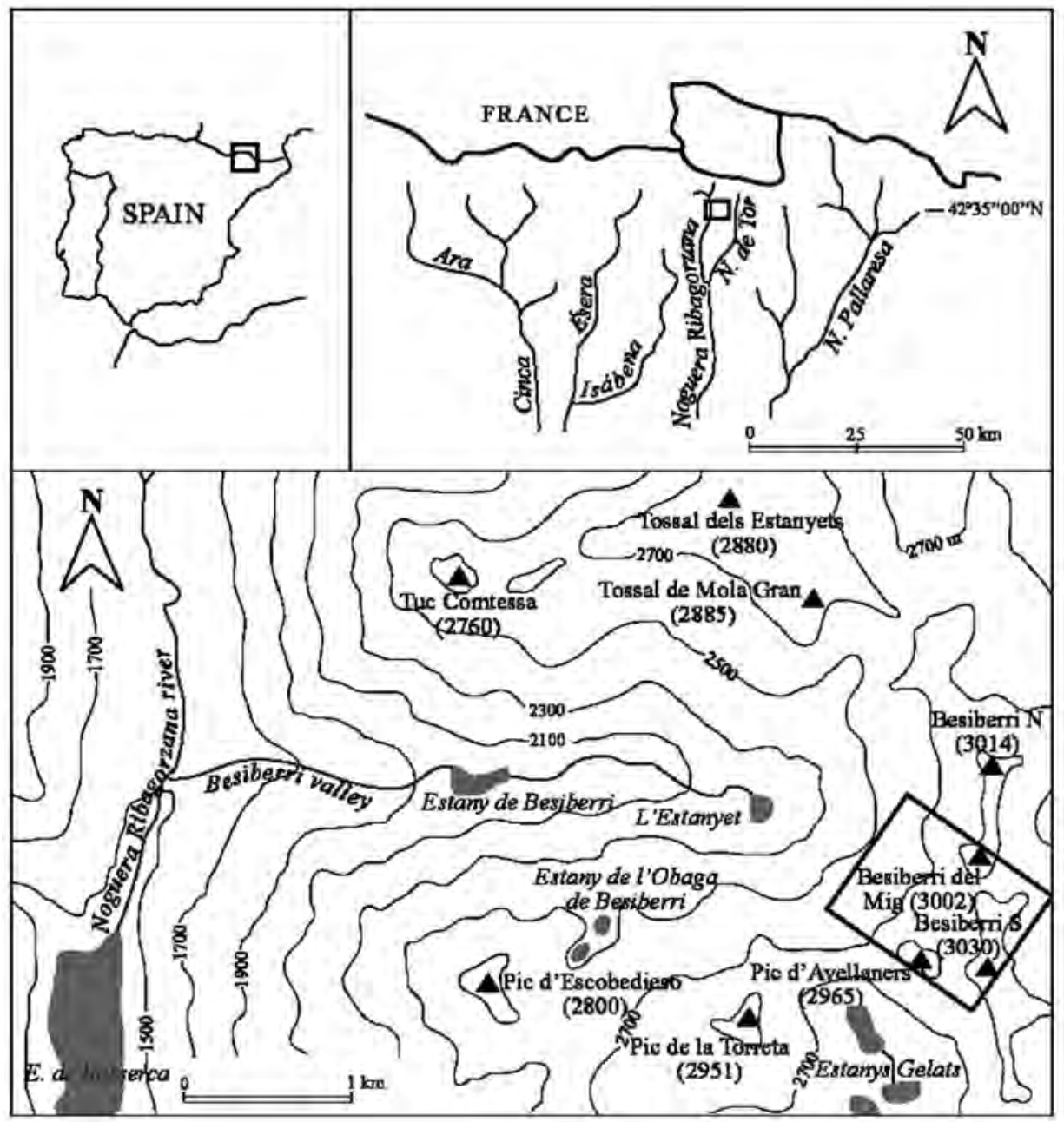

Figure 1. Location of the study site (box in the bottom panel indicates the location of Besiberris rock glacier). 


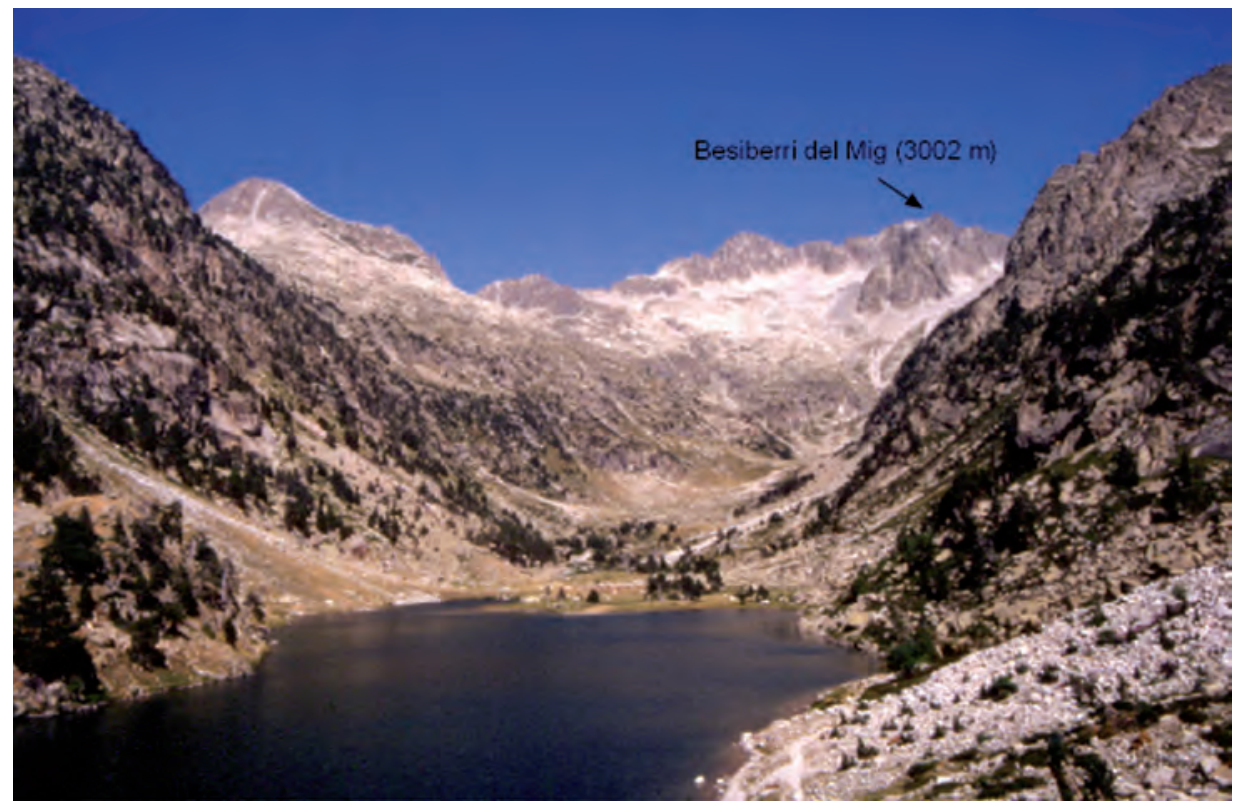

Figure 2. View of the upper part of Besiberris glacial valley. Besiberris rock glacier is located beneath Besiberri del Mig peak.

landscape was glaciated during the Pleistocene. Reduced transformation of these glacial landforms took place during the Holocene, mainly by periglacial and mass-wasting processes. Besiberris is a medium size overdeepened glacial valley (length $5 \mathrm{~km}$; width $3.5 \mathrm{~km}$; maximum altitude, $3030 \mathrm{~m}$; minimum altitude, $1500 \mathrm{~m}$ ) with high rockwalls and strong altitudinal differences between crests and valley bottoms (Fig. 2). Above the treeline (2100-2200 m), slopes of the geoecological alpine and nival stages are covered with rocky debris in their lower sectors and mantled with moraine material in some areas. The Mean Annual Air Temperature of this area varies from $-0.5^{\circ} \mathrm{C}$ at $3000 \mathrm{~m}$ to $+6.8^{\circ} \mathrm{C}$ at $1500 \mathrm{~m}$; however, coldest month average temperatures reaches $-4.3^{\circ} \mathrm{C}$ at $3000 \mathrm{~m}$ and $+0.3^{\circ} \mathrm{C}$ at $1500 \mathrm{~m}$. The Annual precipitation varies from $2600 \mathrm{~mm}(3000 \mathrm{~m})$ to 1400 $\mathrm{mm}(1500 \mathrm{~m})$. Discontinuous and sporadic permafrost has been reported in the nearby Maladeta massif, but detailed studies have not been carried out in the Besiberris area (Chueca and Julián, 1994).

Besiberris rock glacier occupies the floor of a small glacial cirque placed in the

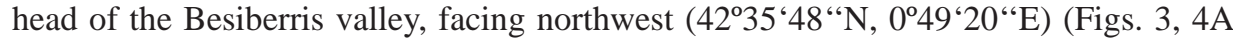
and B). The front slope is at $2570 \mathrm{~m}$ a.s.1., while its head lies at $2780 \mathrm{~m}$. The rock glacier occupies an elongated area left by the retreat of Besiberris glacier since the Little Ice Age (LIA). It has a maximum length of $680 \mathrm{~m}$, and an average width of $250 \mathrm{~m}(380 \mathrm{~m}$, maximum width). The overall slope of the rock glacier is $17^{\circ}\left(11^{\circ}\right.$ head sector; $21^{\circ}$ center sector; $26^{\circ}$ toe sector), and the frontal slope (20-25 $\mathrm{m}$ high) varies between $35^{\circ}$ and $43^{\circ}$. 


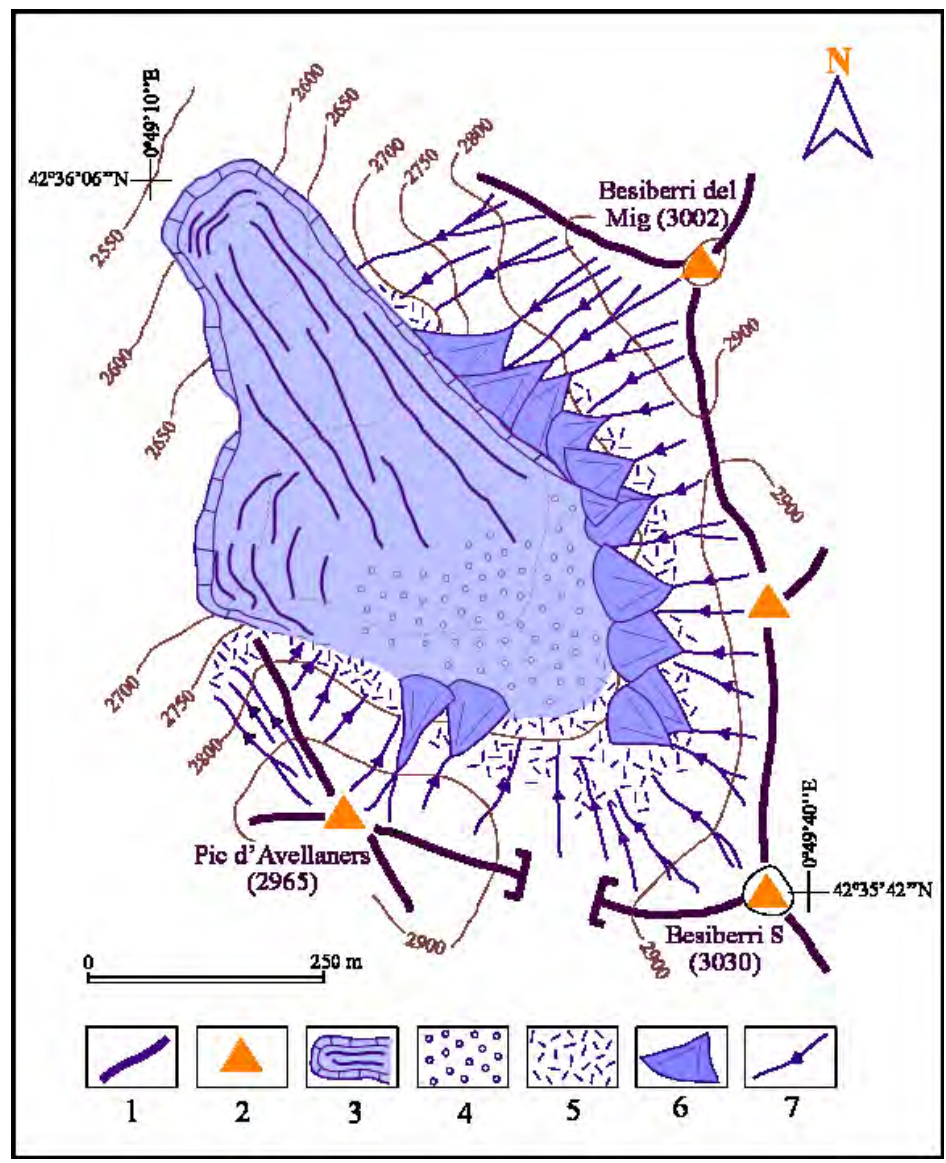

Figure 3. Geomorphological map of the study site, (1) glacial cirque limits, (2) main peaks, (3) Besiberris rock glacier (front slope, lateral ridges and internal main ridges are indicated), (4) rooting zone, (5) talus slopes, (6) avalanche talus cones, (7) main avalanche tracks.

Its surface is composed of angular granites and granodiorites boulders very unstable with an interstitial void ratio up to $50 \%$ (Fig. 4C).

Morphologically, the rock glacier is categorized as tongue-shaped, with a surface topography that shows both extension (longitudinal furrows and ridges lined up along the central axis) and compression (in the toe area and in a small lateral body with marked and well developed traverse furrows) (Fig. 3). In morphogenetical terms, the rock glacier is a debris rock glacier of glacigenic origin, linked to the ice and the morainic deposits generated by the former Besiberris glacier. Talus materials are also incorporated by avalanche processes. Two geo-electrical soundings carried out in the middle portion of the rock glacier (García et al. 1998) suggest the existence of an ice-core (8-18 m thick 

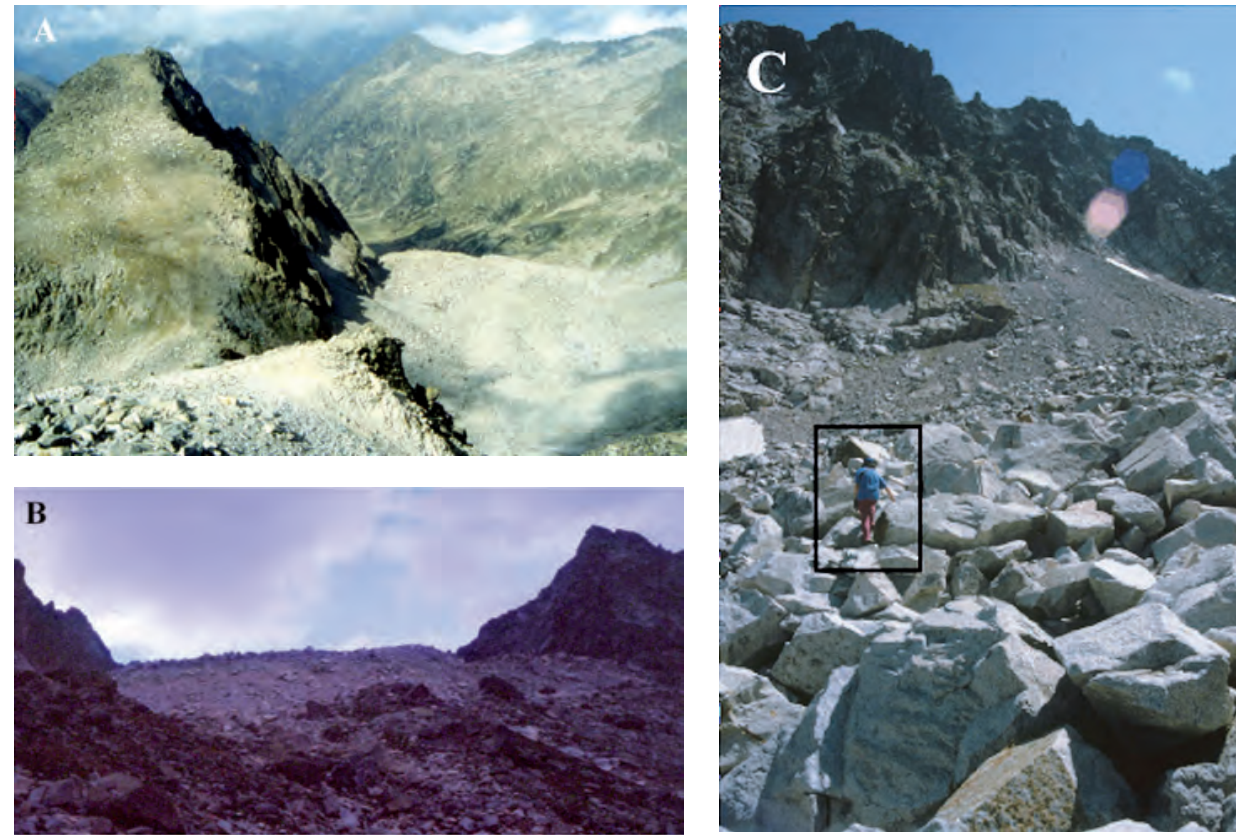

Figure 4. (A) Looking north, a view of the head and center sections of Besiberris rock glacier beneath Pic d'Avellaners. (B) Front slope of Besiberris rock glacier showing evidence of rock slides and micro debris-flow processes. (C) Surface boulders on the longitudinal furrows and ridges along the central axis of the rock glacier (for scale, see person outlined by rectangle).

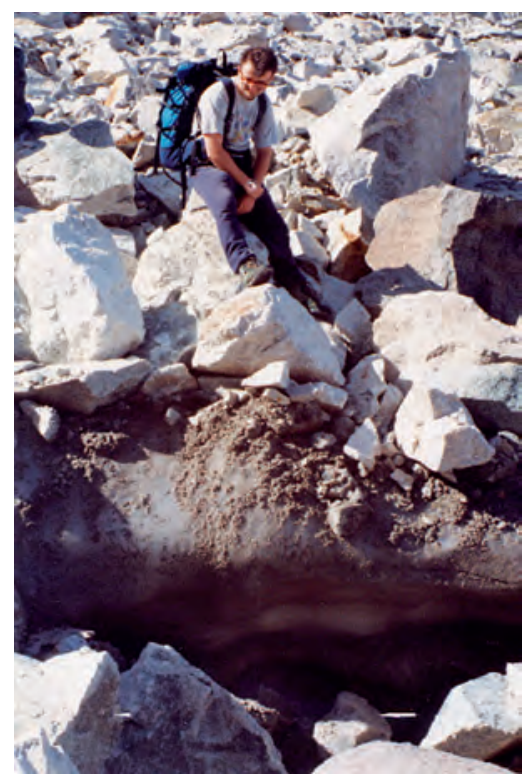

Figure 5. Exposure of the ice-core located in the head area of the rock glacier. 
and partially visible in several exposures located in its proximal section) covered by a coarse-debris layer (1-1.5 m thick) (Fig. 5). During the last decade, most of the previous year winter's snow melted by the end of the summer season; accumulation of snow in the cirque was reduced to small patches located against the cirque headwalls in the contact with the avalanche cones (2750-2800 $\mathrm{m}$ a.s.1.). The amount of ice added to the rock glacier under todays climatic conditions is negligible.

\section{Methods}

In August 1993 the Besiberris rock glacier surface was first surveyed in detail.Geodetic triangulation (Wild T2 theodolite) was utilized to determine the three-dimensional positions of 42 target points (boulders) distributed on three traverse lines which crossed over the rock glacier in its head, center and toe sectors (18 points on A-A'; 14 points on B-B'; 10 points on C-C') (Fig. 6). The selected boulders were well interlocked, stable, medium and large-sized (lengths range from 0.8 to $3 \mathrm{~m}$ ), in order to provide a reliable measure of rock glacier movement. A steel bolt was drilled into each boulder and used as target reflector. Fixed stations were established on both sides of the rock glacier and on the walls of the surrounding cirque in bedrock surfaces. The accuracy of the procedure was better than $\pm 1.0 \mathrm{~cm}$. In order to measure surface displacement over a ten-year period, the same survey protocol was conducted (Leica Total Station) in September 2003. Boulder positions on the three traverse lines were remeasured (four target points,

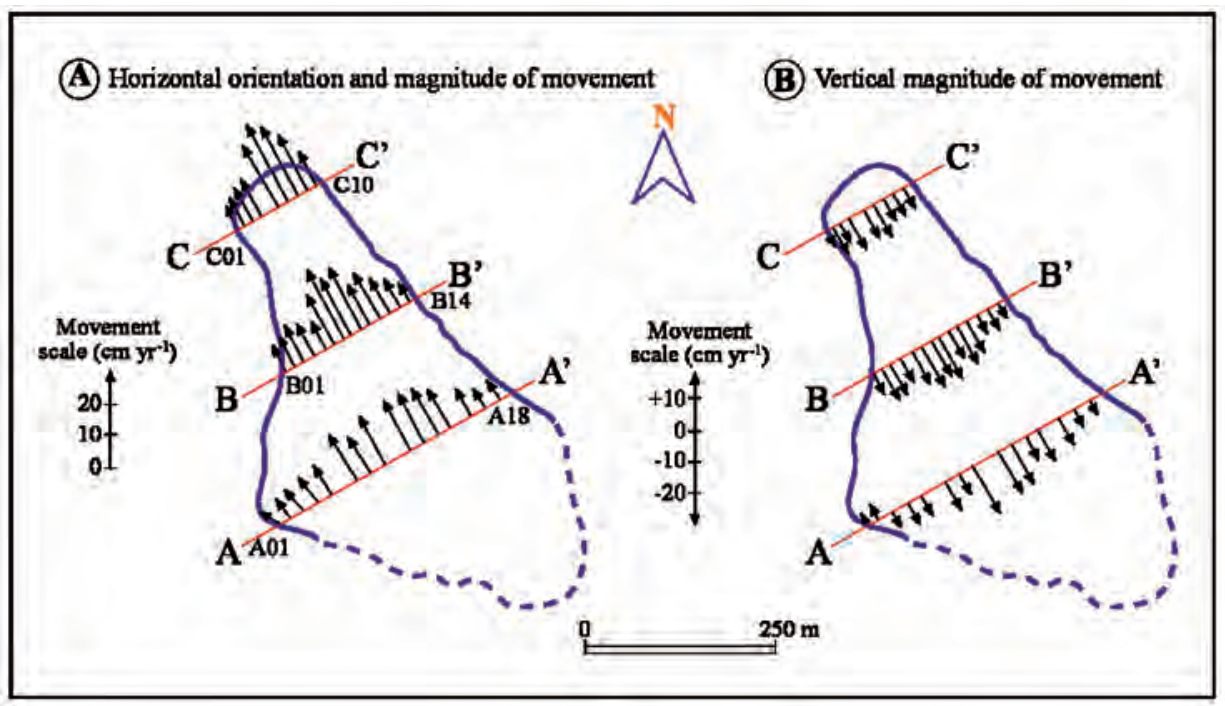

Figure 6. Location on the rock glacier of the three traverse lines $A-A^{\prime}, B-B$ ' and $C-C$ ', and average movement data (horizontal and vertical displacements) for each control point for the period 1993-2003. 


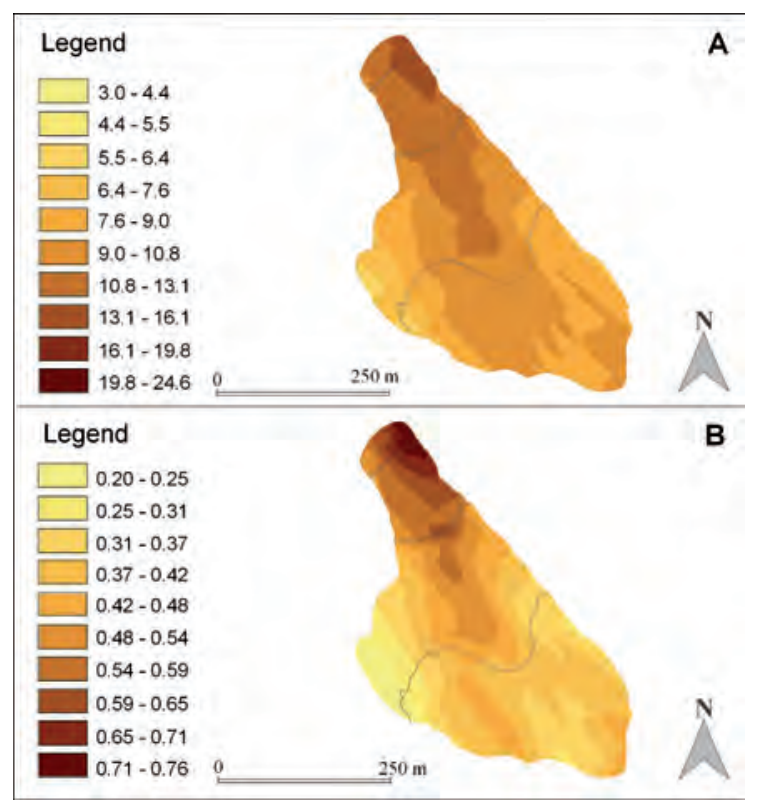

Figure 7. Maps of (A) predicted horizontal movement ( $\mathrm{cm} \mathrm{yr}^{-1}$ ) and $(B)$ probability of exceeding mean horizontal values.

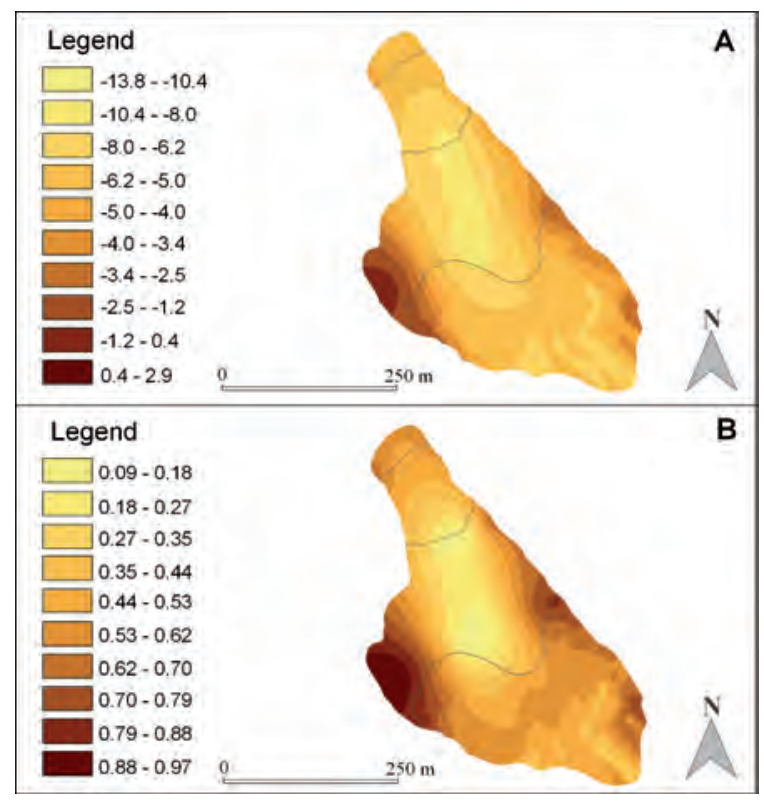

Figure 8. Maps of $(A)$ predicted vertical movement ( $\mathrm{cm} \mathrm{yr}^{-1}$ ) and $(B)$ probability of exceeding mean vertical values. 
placed on the A and C lines were not located, probably due to sliding of the blocks). Targets were located with positional accuracy of better than $\pm 0.5 \mathrm{~cm}$.

Once obtained, the movement data was incorporated into a Geographical Information System (ArcGIS), and its Spatial Analyst Tools module was used to perform a geostatistical analysis in two phases: i) modelling the semivariogram or covariance to analyze surface properties; and ii) kriging (ordinary kriging) analysis to create predicted maps of horizontal and vertical movement and probability maps of exceeding critical thresholds (mean displacement values) (Figs. 7 and 8).

\section{Results and discussion}

The average downvalley movement of surface boulders during the ten-year measurement period shows distinct differences between traverse lines, with an increase in displacement rates from the proximal to the distal sectors of the rock glacier (line A $=8.72 \mathrm{~cm} \mathrm{yr}^{-1}$; line $\mathrm{B}=10.65 \mathrm{~cm} \mathrm{yr}^{-1}$; line $\mathrm{C}=13.35 \mathrm{~cm} \mathrm{yr}^{-1}$ ) (Table 1; Fig. 6). The range of displacements varies from 3.0-16.5 $\mathrm{cm} \mathrm{yr}^{-1}$ in traverse line $\mathrm{A}, 3.2-21.8 \mathrm{~cm} \mathrm{yr}^{-1}$ in traverse line $\mathrm{B}$ and 5.3-24.6 $\mathrm{cm} \mathrm{yr}^{-1}$ in traverse line $\mathrm{C}$. In all three cases, however, the horizontal movement map predicted by kriging, and the associated probability map show higher velocities at the axis of the rock glacier than toward the lateral margins (Fig. 7). This fastest flow in the unstable central section is also evidenced by the observation of lichenometric growth, which is almost imperceptible in comparison with the amount of Rhizocarpon geographicum detected in the stable perimeter area of the rock glacier (Figs. 9 and 10). The increase in velocity from proximal to distal sectors shows that the

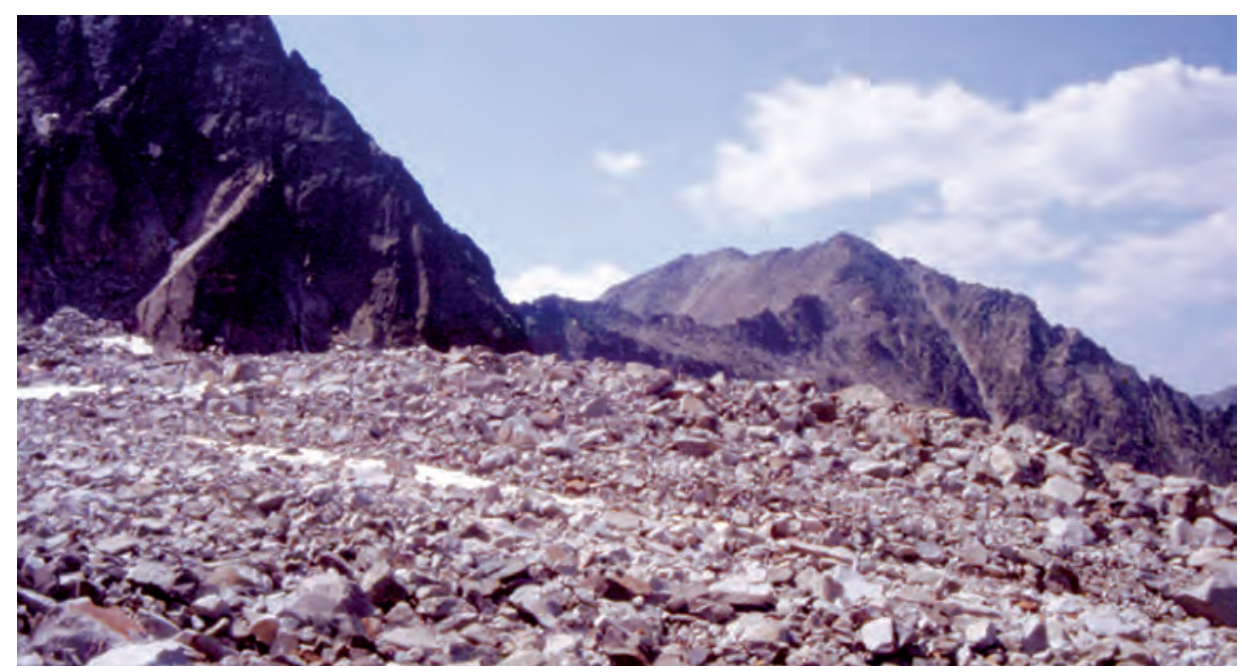

Figure 9. Panoramic of the head section of Besiberris rock glacier looking in the direction of traverse line $A-A$ : 
Table 1. Movement of control points at Besiberris rock glacier, 1993-2003

Movement traverse line A

\begin{tabular}{|c|c|c|c|c|}
\hline \multirow{3}{*}{$\begin{array}{l}\text { Point } \\
\text { no. }\end{array}$} & \multicolumn{2}{|c|}{ Horizontal movement } & \multicolumn{2}{|c|}{ Vertical movement } \\
\hline & \multicolumn{2}{|c|}{ 1993-2003 } & \multicolumn{2}{|c|}{ 1993-2003 } \\
\hline & $\begin{array}{l}\text { Total movement } \\
\qquad(\mathrm{cm})\end{array}$ & $\begin{array}{l}\text { Average } \\
\text { movement } \\
\left(\mathrm{cm} \mathrm{yr}^{-1}\right)\end{array}$ & $\begin{array}{l}\text { Total movement } \\
\qquad(\mathrm{cm})\end{array}$ & $\begin{array}{l}\text { Average } \\
\text { movement } \\
\left(\mathrm{cm} \mathrm{yr}^{-1}\right)\end{array}$ \\
\hline A01 & 34 & 3.4 & +10 & +1.0 \\
\hline A02 & 30 & 3.0 & +29 & +2.9 \\
\hline A03 & 51 & 5.1 & -19 & -1.9 \\
\hline A04 & 56 & 5.6 & -37 & -3.7 \\
\hline A05 & 75 & 7.5 & -33 & -3.3 \\
\hline A06 & Not found & Not found & Not found & Not found \\
\hline A07 & 128 & 12.8 & -64 & -6.4 \\
\hline A08 & 95 & 9.5 & -40 & -4.0 \\
\hline A09 & 165 & 16.5 & -138 & -13.8 \\
\hline A10 & Not found & Not found & Not found & Not found \\
\hline A11 & 143 & 14.3 & -121 & -12.1 \\
\hline A12 & 141 & 14.1 & -107 & -10.7 \\
\hline A13 & 128 & 12.8 & -54 & -5.4 \\
\hline A14 & 111 & 11.1 & -74 & -7.4 \\
\hline A 15 & Not found & Not found & Not found & Not found \\
\hline A16 & 64 & 6.4 & -60 & -6.0 \\
\hline A17 & 42 & 4.2 & -31 & -3.1 \\
\hline A18 & 45 & 4.5 & -11 & -1.1 \\
\hline Mean & 87.2 & 8.72 & 50.0 & -5.0 \\
\hline
\end{tabular}

Movement traverse line B

\begin{tabular}{|c|c|c|c|c|}
\hline \multirow{3}{*}{$\begin{array}{l}\text { Point } \\
\text { no. }\end{array}$} & \multicolumn{2}{|c|}{ Horizontal movement } & \multicolumn{2}{|c|}{ Vertical movement } \\
\hline & \multicolumn{2}{|c|}{$1993-2003$} & \multicolumn{2}{|c|}{$1993-2003$} \\
\hline & $\begin{array}{l}\text { Total movement } \\
(\mathrm{cm})\end{array}$ & $\begin{array}{l}\text { Average } \\
\text { movement } \\
\left(\mathrm{cm} \mathrm{yr}^{-1}\right)\end{array}$ & $\begin{array}{l}\text { Total movement } \\
(\mathrm{cm})\end{array}$ & $\begin{array}{l}\text { Average } \\
\text { movement } \\
\left(\mathrm{cm} \mathrm{yr}^{-1}\right)\end{array}$ \\
\hline B01 & 54 & 5.4 & -38 & -3.8 \\
\hline B02 & 68 & 6.8 & -76 & -7.6 \\
\hline B03 & 95 & 9.5 & -77 & -7.7 \\
\hline B04 & 76 & 7.6 & -51 & -5.1 \\
\hline B05 & 73 & 7.3 & -81 & -8.1 \\
\hline B06 & 143 & 14.3 & -113 & -11.3 \\
\hline B07 & 218 & 21.8 & -90 & -9.0 \\
\hline B08 & 164 & 16.4 & -120 & -12.0 \\
\hline
\end{tabular}




\begin{tabular}{|ccccc|} 
B09 & 197 & 19.7 & -72 & -7.2 \\
B10 & 105 & 10.5 & -99 & -9.9 \\
B11 & 125 & 12.5 & -83 & -8.3 \\
B12 & 81 & 8.1 & -34 & -3.4 \\
B13 & 60 & 6.0 & -46 & -4.6 \\
B14 & 32 & 3.2 & -15 & -1.5 \\
Mean & 106.5 & 10.65 & -71.0 & -7.10 \\
\hline
\end{tabular}

\section{Movement traverse line $\mathbf{C}$}

\begin{tabular}{|c|c|c|c|c|}
\hline \multirow{3}{*}{$\begin{array}{l}\text { Point } \\
\text { no. }\end{array}$} & \multicolumn{2}{|c|}{ Horizontal movement } & \multicolumn{2}{|c|}{ Vertical movement } \\
\hline & \multicolumn{2}{|c|}{ 1993-2003 } & \multicolumn{2}{|c|}{$1993-2003$} \\
\hline & $\begin{array}{l}\text { Total movement } \\
(\mathrm{cm})\end{array}$ & $\begin{array}{l}\text { Average } \\
\text { movement } \\
\left(\mathrm{cm} \mathrm{yr}^{-1}\right)\end{array}$ & $\begin{array}{l}\text { Total movement } \\
(\mathrm{cm})\end{array}$ & $\begin{array}{l}\text { Average } \\
\text { movement } \\
\left(\mathrm{cm} \mathrm{yr}^{-1}\right)\end{array}$ \\
\hline $\mathrm{C} 01$ & 53 & 5.3 & -21 & -2.1 \\
\hline $\mathrm{C} 02$ & 68 & 6.8 & -62 & -6.2 \\
\hline $\mathrm{C} 03$ & 82 & 8.2 & -42 & -4.2 \\
\hline $\mathrm{C} 04$ & 101 & 10.1 & -71 & -7.5 \\
\hline $\mathrm{C} 05$ & Not found & Not found & Not found & Not found \\
\hline $\mathrm{C} 06$ & 190 & 19.0 & -63 & -6.3 \\
\hline $\mathrm{C} 07$ & 246 & 24.6 & -81 & -8.1 \\
\hline $\mathrm{C} 08$ & 216 & 21.6 & -47 & -4.7 \\
\hline $\mathrm{C} 09$ & 167 & 16.7 & -46 & -4.6 \\
\hline $\mathrm{C} 10$ & 79 & 7.9 & -38 & -3.8 \\
\hline Mean & 133.5 & 13.35 & -52.7 & -5.27 \\
\hline
\end{tabular}

main rock glacier body is undergoing extensive flow, a possible origin of the observed longitudinal furrows and ridges parallel to the central axis. Considering the surface slope measured in the head, center and toe areas, a relationship between that parameter and the observed velocity (mean, maximum and minimum values) seems to exist within the Besiberris rock glacier. The lack of detailed knowledge on its internal structure, makes difficult to evaluate the contribution of other factors (thickness, density, temperature; Paterson, 1994) in producing speed differences.

The average velocity of the Besiberris rock glacier was calculated using a model from Barsch (1996), which compares the height of a rock glacier talus apron to the average surface velocity. Average velocity $\left(V_{\mathrm{m}}\right)$ of the entire rock glacier is calculated as:

$$
V_{m}=\left(1-h_{m}\right) \bar{V}_{s}
$$

where $h_{m}$ is the ratio of the talus height to the height of the front slope and $\bar{V}_{s}$ is the mean surface velocity. For the Besiberris rock glacier $h_{m}=0.25$ and $\bar{V}_{s}=10.90 \mathrm{~cm} \mathrm{yr}^{-1}$; therefore, the entire rock glacier should have moved at a rate of $8.17 \mathrm{~cm} \mathrm{yr}^{-1}$. However, 


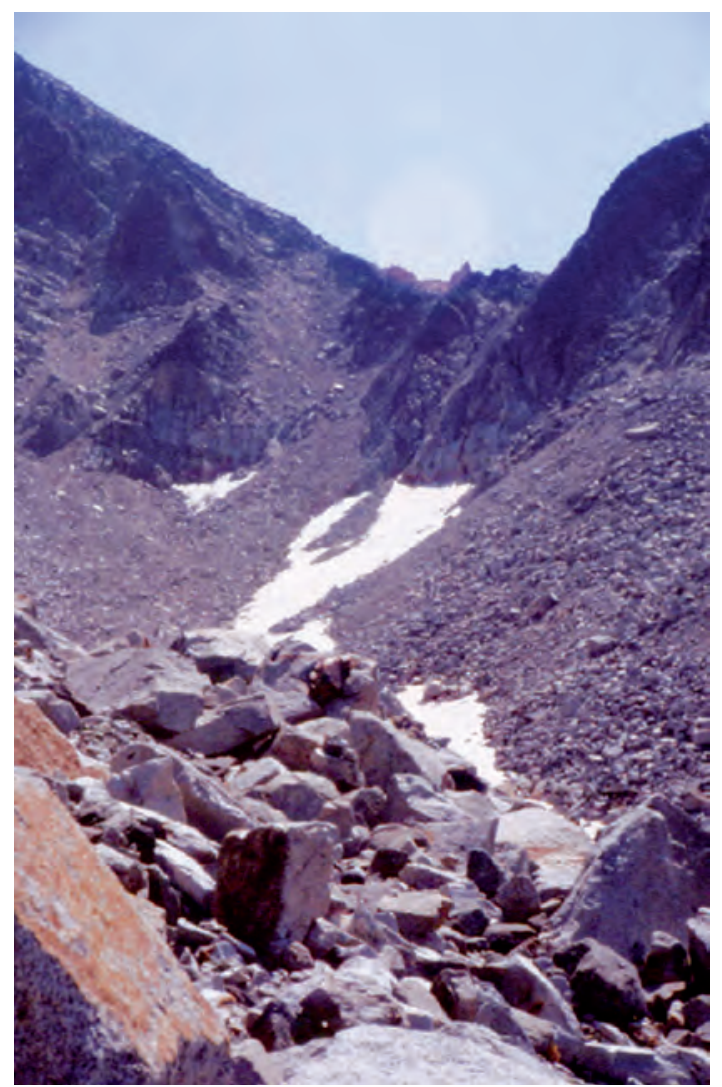

Figure 10. View of the proximal western section of Besiberris rock glacier lateral ridge. Visible are small patches of snow against the cirque headwalls and the contact zone between the rock glacier lateral ridge and avalanche talus cones.

as Clark et al. (1998) have pointed out, this model relies on the underlying assumption that rock glaciers consist predominantly of ice-cemented debris. In glacigenic derived rock glaciers with massive ice cores, the velocity value obtained may relate more to the rate of advance of the rock glacier terminus than to the entire rock glacier velocity.

In terms of vertical movement, the rock glacier is showing clear subsidence. In all three traverse lines surface lowering has been detected (average values: line $\mathrm{A}=5.00 \mathrm{~cm} \mathrm{yr}^{-1}$; line $\mathrm{B}=7.10 \mathrm{~cm} \mathrm{yr}^{-1}$; line $\mathrm{C}=5.27 \mathrm{~cm} \mathrm{yr}^{-1}$ ). The subsidence ranges from $1.1-13.8 \mathrm{~cm} \mathrm{yr}^{-1}$ in line $\mathrm{A}$; $1.5-12.0 \mathrm{~cm} \mathrm{yr}^{-1}$ in line $\mathrm{B}$; and 2.1-8.1 $\mathrm{cm} \mathrm{yr}^{-1}$ in line $\mathrm{C}$ (Table 1; Fig. 6). As the vertical movement map predicted by kriging, and the associated probability map show (Fig. 8), the total ablation is greater in the central traverse line $(71.0 \mathrm{~cm})$ than in the proximal $(50.0 \mathrm{~cm})$ and distal $(52.7 \mathrm{~cm})$ traverses and is also much more distinct near the axis than in the outermost ridges. The pattern is very similar to the observed at the glacigenic Galena Creek rock glacier (Konrad et al., 1999) and is probably linked to the existence of an increase in insulating surface debris that reduces ablation rates both 
toward the rock glacier terminus and toward the head: in the first case due to the advance of the rock glacier and, in the second, in relation to the continuous incorporation of talus materials by avalanche processes.

The velocity measurements presented here are consistent with those cited in the literature, commonly placed between 0.1 and $1.0 \mathrm{~m} \mathrm{yr}^{-1}$ (Whalley and Martin, 1992; Barsch, 1996; Sloan and Dyke, 1998; Shroder et al. 2000). Comparison with the only previous detailed studies of rock glacier dynamics in the Pyrenees on Argualas and Posets rock glaciers (Serrano et al., 2006, 2010), shows that Besiberris rock glacier has similar magnitude rates of horizontal and vertical displacement. However, while Besiberris is a glacier-derived form, Argualas and Posets rock glaciers have been classified as of periglacial origin. The morphogenetical disparity (and associated parameters such as density, thickness or temperature) makes it difficult to directly compare displacement rates from the three rock glaciers. Additionally, factors as surface slope, aspect or lithology of the area are also different. It is important to note that velocity values for glacigenic derived rock glaciers were probably much higher at the LIA maximum, when ice thickness was greater (Whalley et al., 1995). After decades of subsidence processes linked to ice degradation, flow velocities on Besiberris rock glacier have been reduced to the current low rates.

To complement the analysis of the movement of the rock glacier, its basal shear stress $\tau$ has been calculated following the standard equation for laminar flow:

$$
\tau=\delta z g \sin \alpha
$$

where $\delta$ is density of the rock glacier, $z$ is thickness (derived in our case from the geoelectrical soundings; $19.5 \mathrm{~m}), g$ is acceleration due to gravity and $\alpha$ is surface slope $\left(17^{\circ}\right)$. Typically, many studies have assumed a density $(\delta)$ of $\sim 1.8 \mathrm{~g} \mathrm{~cm}^{-3}$, which corresponds to a 50/50 volumetric mix of debris and interstitial ice (Wahrhaftig and Cox, 1959; Haeberli, 1985; Barsch, 1996). Clark et al. (1998) suggested that a much more appropriate density value for an ice-cored rock glacier should be $\delta \sim 1.0 \mathrm{~g} \mathrm{~cm}^{-3}$. Using both density values, we estimated the basal shear stress at Besiberris rock glacier to be between $100 \mathrm{kPa}\left(\delta=1.8 \mathrm{~g} \mathrm{~cm}^{-3}\right)$ and $55 \mathrm{kPa}\left(\delta=1.0 \mathrm{~g} \mathrm{~cm}^{-3}\right)$. The values are lower than those reported by Haeberli (1985) and Barsch (1996) for several active rock glaciers, but higher than the cases cited by Wagner (1992) for the Murtèl rock glacier or Koning and Smith (1999) for King's Throne rock glacier. Nevertheless, assuming any of the two density values the basal shear stress obtained for Besiberris rock glacier is in the range cited for this parameter at the base of most glaciers flowing over bedrock (50-100 kPa; Paterson, 1994).

Studies by Chueca et al. (1998) and Chueca and Julián (2002) have shown significant losses in surface, thickness and volume of all Pyrenean glaciers since the LIA maximum (1820-1830). Those losses are linked to the climatic amelioration (higher temperature; drier conditions and reduced snowfall) observed in the Pyrenean region since the end of the LIA and accentuated in the last few decades (Chueca et al., 2003, 2005, 2007; López-Moreno et al., 2006). Even if protected by the layer of insulating 
debris, the probable reduction of thickness in Besiberris rock glacier ice-core by this atmospheric warming must have contributed in recent decades to a lowering in the basal shear stress values, which are now near the limit of ice deformation and help explain the low flow rates observed.

\section{Conclusions}

Displacements for the Besiberris rock glacier are consistent with those obtained for other rock glaciers. Average horizontal flow rates from 8.72 to $13.35 \mathrm{~cm} \mathrm{yr}^{-1}$ and subsidence values from 5.00 to $7.10 \mathrm{~cm} \mathrm{yr}^{-1}$ have been obtained over a ten-year period. Horizontal velocity increases from the proximal to the distal sector of the rock glacier. Extensional flow dominates as inferred from increasing surface velocities from head to toe. Unstability along the central axis and more stable lateral margins suggest deterioration of an ice-core.

If higher temperature, drier conditions and reduced snowfall continue, ice-core ablation could lead toward a reduction of Besiberris rock glacier flow rate. As Potter et al. (1998) suggested, rock glaciers of glacigenic origin placed in an adverse climatic situation are starved systems in which the small accumulation of snow and ice is kept in balance only by the debris mantle that reduces ablation beneath it. Whalley et al. (1995) have also indicated that with this configuration, the progressive thinning of the ice-core will give a reduction in velocity and, eventually, halt flow. In that context, only a sufficient amount of matrix debris could maintain the rock glacier movement. Further investigation of horizontal and subsidence displacements on the Besiberris rock glacier will help to address these questions properly.

\section{Acknowledgements}

Financial support for this study was provided by the Gobierno de Aragón and is part of the project 'Estudio de la dinámica de los glaciares del Pirineo aragonés'. The authors would like to thank A. Castro, J. Santos, F. Santos and A. Pérez for their assistance in the field.

\section{References}

BARSCH, D., (1996). Rockglaciers: Indicators for the present and former geoecology in high mountain environments. Springer-Verlag, 331 pp., Heidelberg.

Benedict, J.B., Benedict, R.J., SAnville, D., (1986). Arapaho rock glacier: A 25 year resurvey. Arctic and Alpine Research, 18: 349-352. 
ChuecA, J., (1991). Aplicación de métodos de análisis factorial en el establecimiento de una tipología de los glaciares rocosos del Pirineo Central oscense. Cuaternario y Geomorfología, 5: 27-43.

ChuecA, J., (1992). A statistical analysis of the spatial distribution of rock glaciers, Spanish Central Pyrenees. Permafrost and Periglacial Processes, 3: 261-265.

ChuecA, J., (1994). Modelos de flujo en glaciares rocosos pirenaicos. In: El glaciarismo surpirenaico: nuevas aportaciones (Martí-Bono, C., García-Ruiz, J.M., Eds.), Geoforma, Logroño, 91-109.

Chueca, J., Julí́n, A., (1994). El medio natural de la Alta Ribagorza: macizo de la Maladeta. Col. Naturalia, 155 pp., Madrid.

ChueCA, J., Julián, A., (2002). Los glaciares pirenaicos aragoneses: estudio de su evolución desde el final de la Pequeña Edad del Hielo hasta la actualidad a través de documentación fotográfica. Diputación de Huesca, 323 pp., Huesca.

ChueCA, J., Julián, A., (2005). Movement of Besiberris rock glacier, Central Pyrenees, Spain: data from a 10-year geodetic survey. Arctic, Antarctic, and Alpine Research, 37 (2): 163-170.

ChueCA, J. Julián, A., LAMPRE, F., (1992). Measurement of surficial dynamics in Besiberris active rock glacier. Lurralde, 15: 45-50.

Chueca, J., Peña, J.L., Lampre, F., García-Ruiz, J.M., Martí-Bono, C., (1998). Los glaciares del Pirineo aragonés: estudio de su evolución y extensión actual. Universidad de Zaragoza, 104 pp., Zaragoza.

ChuecA, J., Julián, A., LóPeZ-Moreno, J.I., (2003). Variations of Glaciar Coronas, Pyrenees, Spain, during the 20th century. Journal of Glaciology, 49 (166): 449-455.

Chueca, J., Julián, A., SAZ, M.A., Creus, J., LóPez-Moreno, J.I., (2005). Responses to climatic changes since the Little Ice Age on Maladeta Glacier (Central Pyrenees). Geomorphology, 68: 167-182.

ChueCA, J., Julián, A., LóPEZ-Moreno, J.I., (2007). Recent evolution (1981-2005) of the Maladeta glaciers, Pyrenees, Spain: extent and volume losses and their relation with climatic and topographic factors. Journal of Glaciology, 53 (183): 547-557.

Clark, D.H., Steig, E.J., Potter, N., Gillespie, A.R., (1998). Genetic variability of rock glaciers. Geografiska Annaler, 80A: 175-182.

FRANCOU, B., REYNAUD, L., (1992). 10 year surficial velocities on a rock glacier (Laurichaud, French Alps). Permafrost and Periglacial Processes, 3: 209-213.

García, F., Cantarino, I., Serrano, E., (1998). Primeros estudios mediante prospección geoeléctrica en el aparato glaciar de Besiberri, Pirineo catalán (Lleida). Ería, 45: 82-87. 
Gorbunov, A.P., TitKov, S.N., Polyakov, V.G., (1992). Dynamics of rock glaciers of the Northern Tien Shan and the Dujungar Ala Tau, Kazahkstan. Permafrost and Periglacial Processes, 3: 29-39.

HAEBERLI, W., (1985). Creep of mountain permafrost: internal structure and flow of alpine rock glaciers. Mitteilungen der Versuchsanstalt für Wasserbau, Hydrologie und Glaziologie, 77: 1-142.

KÄÄB, A., (2006). Remote Sensing of Mountain Glaciers and Permafrost Creep. Schritenreihe Physische Geographie, glaziologie und geomorphodynamic. Geographie Institut of Universitat Zurich, Zurich.

KäÄB, A., HAeBerli, W., Gudmundsson, G.H., (1997). Analysing the creep of mountain permafrost using high precision aerial photogrammetry: 25 years of monitoring Gruben rock glacier, Swiss Alps. Permafrost and Periglacial Processes, 8: 409-426.

KÄÄB, A., ISAKSEN, K., EIKEN, T., FARBROT, H., (2002). Geometry and dynamics of two lobe-shaped rock glaciers in the permafrost of Svalbard. Norsk Geografisk Tidsskrift, 56: 152-160.

KAUfMANN, V., (1998). Geomorphometric monitoring of active rock glaciers in the Austrian Alps. 4th International Symposium on High Mountain Remote Sensing Cartography, pp. 97-113.

KAUfMANN, V., LADSTÄDTER, R., (2003). Quantitative analysis of rock glacier creep by means of digital photogrammetry using multi-temporal aerial photographs: two case studies in the Austrian Alps. 8th International Conference on Permafrost, pp. $525-530$.

Koning, D.M., SMITH, D.J., (1999). Movement of King's Throne rock glacier, Mount Rae area, Canadian Rocky Mountains. Permafrost and Periglacial Processes, 10: $151-162$.

Konrad, S.K., Humphrey, N.F., Steig, E.J., Clark, D.H., Potter, N., Pfeffer, W.T., (1999). Rock glacier dynamics and paleoclimatic implications. Geology, 27: 1131-1134.

López-Moreno, J.I., Nogués, D., ChueCA, J., Julián, A., (2006). Change of topographic control on the extent of cirque glaciers since the Little Ice Age. Geophysical Research Letters, 33: L24505.

PATERSON, W.S.B., (1994). The Physics of Glaciers. Pergamon, 480 pp., Oxford.

PotTer, N., (1972). Ice-cored rock glacier, Galena Creek, northern Absaroka Mountains, Wyoming. Geological Society of America Bulletin, 83: 3025-3058. 
Potter, N., Steig, E.J., Clark, D.H., Speece, M.A., Clark, G.M., Updike, A.B., (1998). Galena Creek rock glacier revisited- new observations on an old controversy. Geografiska Annaler, 80A: 251-265.

Serrano, E., Martínez de Pisón, E., Martínez, R., Cantarino, I., Navarro, J., (1991). El glaciar noroccidental del Besiberri (Pirineo de Lérida). Pirineos, 137: 95-109.

Serrano, E., Agudo, C., Martínez de Pisón, E., (1999). Rock glaciers in the Pyrenees. Permafrost and Periglacial Processes, 10: 101-106.

Serrano, E., SAnjosé, J.J., Agudo, C., (2006). Rock glacier dynamic in a marginal periglacial high mountain environment: flow, movement (1991-2000) and structure of the Argüalas rock glacier. Geomorphology, 74: 285-296.

Serrano, E., Sanjosé, J.J., GonzÁlez-Trueba, J.J., (2010). Rock glacier dynamics in marginal periglacial environments. Earth Surface Processes and Landforms, 35: 1302-1314.

Shroder, J.F., Bishop, M.P., Copland, L., SloAn, V.F., (2000). Debris-covered glaciers and rock glaciers in the Nanga Parbat Himalaya, Pakistan. Geografiska Annaler, 82A: 17-31.

SlOAN, V.F., DYKE, L.D., (1998). Decadal and millennial velocities of rock glaciers, Selwyn Mountains, Canada. Geografiska Annaler, 80A: 237-249.

Sollid, J.L., SøRBel, L., (1992). Rock glaciers in Svalbard and Norway. Permafrost and Periglacial Processes, 3: 215-220.

WAGNER, S., (1992). Creep of alpine permafrost, investigated on the Murtèl rock glacier. Permafrost and Periglacial Processes, 3: 157-162.

WAHrhaftig, C., CoX, A., (1959). Rock glaciers in the Alaska Range. Geological Society of America Bulletin, 70: 383-436.

Whalley, W.B., Martin, H.E., (1992). Rock glaciers: II Models and Mechanisms. Progress in Physical Geography, 16: 127-186.

Whalley, W.B., Palmer, C.F., Hamilton, S.J., Martin, H.E., (1995). An assessment of rock glacier sliding using seventeen years of velocity data: Nautárdalur rock glacier, North Iceland. Arctic and Alpine Research, 27: 345-351. 